\title{
Anti-oxidative Activity of Nepalese Traditional Anti-diabetic Medicines
}

\author{
H. P. Devkota, ${ }^{1,2}$ A. Adhikari-Devkota, ${ }^{1}$ S. Yahara ${ }^{2}$ and P. Basnet ${ }^{1,3}$ \\ ${ }^{1}$ Faculty of Science and Technology, Pokhara University, P.O. Box 427, Lekhnath, Kaski \\ ${ }^{2}$ Graduate School of Pharmaceutical Sciences, Kumamoto University, 5-1 \\ Oe-honmachi, Chuo-ku,Kumamoto 862-0973, Japan \\ ${ }^{3}$ IVF Unit, Department of Obstetrics and Gynecology, University Hospital of North Norway and \\ Department of Clinical Medicine, University of Tromsø, Tromsø, Norway \\ e-mail:devkotah@hotmail.com
}

\begin{abstract}
Chronic overproduction of free radicals in human body has a role in numerous disease states including diabetes. Proper use of antioxidants may help in the prevention and/or treatment of diabetes. For the management of diabetes, a combination of herbal drugs is being practiced traditionally in Nepal. These herbal medicines might have a good correlation to anti-oxidative properties. Anti-oxidative property was evaluated with the methanolic extracts of nineteen common traditional anti-diabetic medicines by 1,1-diphenyl-2-picrylhydrazyl (DPPH) radical scavenging method. Among the evaluated herbal medicines, Phyllanthus emblica, Punica granatum, Syzygium cumini, Terminalia bellirica and Terminalia chebula showed potent radical scavenging activity. The activities of $P$. emblica, T. bellirica and T. chebula were more potent than that of ascorbic acid. Some of the reported popular hypoglycemic herbal drugs did not show strong activity. Therefore strong anti-oxidative herbal drugs in combination with hypoglycemic drugs might have better results in the management of diabetes.
\end{abstract}

Key words: antioxidant, diabetes, DPPH, free radicals, traditional medicines

\section{Introduction}

Reactive oxygen species (ROS) such as superoxide ions $\left(\mathrm{O}_{2} \ddot{\mathrm{y}}\right)$, hydroxyl (HOÿ) and nitric oxide (NÖ̈) radicals along with non-free radical species such as hydrogen peroxide $\left(\mathrm{H}_{2} \mathrm{O}_{2}\right)$ and nitrous acid $\left(\mathrm{HNO}_{2}\right)$ are involved in normal cell regulation process (Droge 2002). Overproduction of ROS weaken the natural antioxidant system in body, first resulting in oxidative stress, and then leading to oxidative injury and finally to numerous disease states including diabetes (Robertson 2004), cardiovascular diseases (Asplund 2002), retinal ischemia, cancer, neurodegenerative disorders such as Alzheimer's disease (Delagarza 2003), Parkinson's disease (Packer et al. 2000), and aging processes (Beckman \& Ames 1996).

The number of diabetic population is increasing due to food habit changes, aging, urbanization, increasing prevalence of obesity and physical inactivity. The prevalence of diabetes for all age groups worldwide was estimated to be $2.8 \%$ in 2000 and $4.4 \%$ in 2030 . The total number of people with diabetes is projected to rise from 171 million in 2000 to 366 million in 2030 (Wild et al. 2004). There are considerable evidences that hyperglycemia results in generation of ROS, ultimately leading to increased oxidative stress in varieties of tissues. In the absence of an appropriate compensatory response from indigenous antioxidant network, the system becomes overwhelmed (redox imbalance) leading to activation of stress-sensitive intracellular signaling pathways (Packer et al. 2000). One of the major consequences is the production of gene products that cause cellular damage and are ultimately responsible for late complication of diabetes like insulin resistance, retinopathy, neuropathy and cardiovascular problems like atherosclerosis (Vincent 
et al. 2004, Evans et al. 2002). In animal model, Streptozotocin (STZ) induced diabetes, free radicalmediated toxicity particularly to pancreatic $\beta$ cells and nitric oxide free radicals, which played a central role (Kaneto et al. 1995, Turk et al. 1993). Antioxidants like vitamin $\mathrm{C}, \mathrm{E}$ and ?-lipoic acid have been found to be beneficial in preventing diabetes and diabetic complications (Packer et al. 2000). Various traditional medicines (Basnet et al. 1995) and plant species(Bnouham et al. 2006) have been screened for their anti-diabetic activity in animal models, however, their beneficial effect may be due to potent anti-oxidative activity of plant polyphenols or some other mechanisms remained to be explored.

Traditionally, various herbal remedies have been used for the treatment of diabetes in Nepal (Manandhar 2002).
Therefore, it is important to evaluate their anti-oxidative activities and no such comprehensive study has been reported on Nepalese traditional anti-diabetic medicines. Previously, we have reported the antioxidant activity of common natural medicines (Devkota et al. 2006) and wild edible fruits (Chalise et al. 2010) from Nepal. In continuation, we have evaluated the anti-oxidative activity of Nepalese traditional anti-diabetic medicines by 1,1-diphenyl-2-picrylhydrazyl (DPPH) radical scavenging method.

\section{Methodology}

\section{Chemicals}

1,1-Diphenyl-2-picrylhydrazyl (DPPH) was purchased from Wako Pure Chemicals Co. Ltd., Osaka, Japan. HPLC grade methanol (Merck Limited, India) was used for the

Table 1. DPPH free radical scavenging activity of the methanolic extracts of Nepalese plants traditionally used as medicines

\begin{tabular}{|c|c|c|c|c|c|c|c|}
\hline \multirow[t]{2}{*}{ S.N. } & \multirow[t]{2}{*}{ Scientific Name } & \multirow[t]{2}{*}{ Family } & \multirow{2}{*}{$\begin{array}{l}\text { Local } \\
\text { Name }\end{array}$} & \multirow[t]{2}{*}{ Parts Used } & \multicolumn{3}{|c|}{ DPPH radical scavenged (\%) ${ }^{\mathrm{a}}$} \\
\hline & & & & & 10 & 50 & $100 \mathrm{~g} / \mathrm{ml}$ \\
\hline 1 & Aegle marmelos Corr. & Rutaceae & Bel & Fruit & $34.4 \pm 4.8$ & $53.5 \pm 5.7$ & $65.1 \pm 1.1$ \\
\hline 2 & Asparagus racemosus Willd. & Asparagaceae & Kurilo & Root & $22.2 \pm 0.5$ & $34.2 \pm 2.1$ & $44.1 \pm 5.0$ \\
\hline 3 & Azadirachta indica A. Juss. & Meliaceae & Neem & Leaf & $10.0 \pm 3.8$ & $12.9 \pm 2.2$ & $17.1 \pm 3.1$ \\
\hline 4 & Berberis aristata de Candolle & Berberidaceae & Chutro & Root & $15.1 \pm 0.1$ & $22.3 \pm 0.2$ & $29.6 \pm 1.5$ \\
\hline 5 & Coriandrum sativum $\quad$ L. & Umbelliferae & Dhaniya & Leaf & $7.0 \pm 2.7$ & $19.5 \pm 3.0$ & $37.5 \pm 6.1$ \\
\hline 6 & Curcuma longa $\quad$ L. & Zingiberaceae & Besar & Rhizome & $44.6 \pm 0.5$ & $59.2 \pm 0.5$ & $64.2 \pm 0.2$ \\
\hline 7 & Momordica charantia L. & Cucurbitaceae & Karela & Fruit peel & $15.7 \pm 3.1$ & $18.9 \pm 2.0$ & $28.8 \pm 3.7$ \\
\hline 8 & Nardostachys grandiflora DC. & Valerianaceae & Jatamansi & Rhizome & $10.7 \pm 3.1$ & $12.9 \pm 1.0$ & $34.8 \pm 7.7$ \\
\hline 9 & Ocimum tenuflorum L. & Labiatae & Tulsi & Aerial part & $35.2 \pm 2.8$ & $70.2 \pm 0.9$ & $88.8 \pm 0.4$ \\
\hline 10 & Phyllanthus emblica L. & Euphorbiaceae & Amala & & $93.3 \pm 0.2$ & $95.5 \pm 0.3$ & $94.8 \pm 0.7$ \\
\hline 11 & $\begin{array}{l}\text { Picrorhiza scrophuliiflora } \\
\text { Ponnel }\end{array}$ & Scrophulariaceae & Kutki & Rhizome & $16.1 \pm 3.2$ & $37.2 \pm 5.4$ & $69.1 \pm 4.3$ \\
\hline $\begin{array}{l}12 \\
13\end{array}$ & $\begin{array}{l}\text { Punica granatum L. } \\
\text { Swertia chirata L. }\end{array}$ & $\begin{array}{l}\text { Punicaceae } \\
\text { Gentianaceae }\end{array}$ & $\begin{array}{l}\text { Anar } \\
\text { Chiraito }\end{array}$ & $\begin{array}{l}\text { Wrult peel } \\
\text { Whole plant }\end{array}$ & $\begin{array}{l}89.9 \pm 0.5 \\
11.0 \pm 4.3\end{array}$ & $\begin{array}{l}93.5 \pm 0.4 \\
14.9 \pm 3.1\end{array}$ & $\begin{array}{l}95.3 \pm 0.9 \\
24.7 \pm 1.8\end{array}$ \\
\hline 14 & Syzygium cumini Skeels & Myrtaceae & Jamun & Fruit & $88.6 \pm 0.4$ & $90.5 \pm 0.7$ & $92.3 \pm 1.4$ \\
\hline 15 & Terminalia bellirica Gaertn & Combretaceae & Barro & Fruit & $93.6 \pm 0.2$ & $94.4 \pm 0.2$ & $94.3 \pm 0.3$ \\
\hline 16 & Terminnalia chebula Retz & Combretaceae & Harro & Fruit & $91.9 \pm 2.2$ & $94.6 \pm 2.2$ & $94.8 \pm 0.3$ \\
\hline 17 & Tinospora sinensis Merrill & Menispermaceae & Gurjo & Stem & $13.7 \pm 4.3$ & $14.8 \pm 3.4$ & $18.1 \pm 6.8$ \\
\hline 18 & Trigonella foenum-graceum L. & Papilionaceae & Methi & Seed & $5.2 \pm 3.2$ & $7.2 \pm 2.3$ & $7.8 \pm 3.8$ \\
\hline 19 & Urtica dioica $\mathrm{L}$. & Urticaceae & Sisnu & $\begin{array}{l}\text { Young } \\
\text { Shoots }\end{array}$ & $34.1 \pm 4.6$ & $42.8 \pm 5.2$ & $58.6 \pm 2.1$ \\
\hline 20 & Ascorbic acid & & & & $92.6 \pm 0.5$ & $94.8 \pm 0.3$ & $96.0 \pm 0.9$ \\
\hline
\end{tabular}

${ }^{a}$ Results are expressed as mean \pm SD $(n=3)$. 
DPPH assay. Ascorbic acid was the product of Qualigens Fine Chemicals, India. All the chemicals used were of analytical grades.

\section{Collection of crude drugs}

Nineteen selected Nepalese traditional anti-diabetic herbal medicines were collected from the Pokhara valley, Nepal. They were identified by comparing literature (Manandhar, 2002) and authentic samples. Voucher specimens were preserved in the museum of materia medica, the school of pharmaceutical and biomedical sciences, Pokhara University, Nepal. The list of the natural medicines included in the present study is given as in the Table 1 .

\section{Preparation of extracts}

Dried and ground sample of each of the natural medicine (50 g) was percolated with methanol (300 ml) at room temperature for 24 hours. After filtration, the extracts were concentrated to thick viscous mass under rotary evaporator and a portion of the extract was then dried completely in the desiccators at room temperature.

\section{Determination of DPPH radical scavenging activity}

DPPH radical scavenging activity was measured as described in our previous reports ((Devkota et al. 2006, Chalise et al. 2010). Briefly, $1 \mathrm{ml}$ of methanolic solution of each extract at various concentrations (10, 50 and $100 \mu \mathrm{g} / \mathrm{ml}$ ) was mixed with $1 \mathrm{ml}$ of methanolic solution of DPPH $(60 \mu \mathrm{m})$. The reaction mixture was shaken vigorously and left for 30 minutes at room temperature in dark. The anti-oxidative activity of extracts corresponding to the scavenging of DPPH radicals was measured at $520 \mathrm{~nm}$ with UV spectrophotometer using following formula:

Radical scavenging activity $(\%)=100 \times(A-B) / A$

where, $\mathrm{A}$ is the control absorbance of DPPH radicals without samples and B is the absorbance after reacting with samples. Ascorbic acid was used as the positive control. The result is expressed as mean of three experiments.

Those natural medicines which showed potent radical scavenging activity were again analyzed at the concentration of 1, 2, 5, 10, 15 and $20 \mu \mathrm{g} / \mathrm{ml}$. From these data a curve was plotted and effective concentration $\left(\mathrm{EC}_{50}\right)$ value was calculated which is defined as the concentration $(\mu \mathrm{g} / \mathrm{ml})$ of the extract required for $50 \%$ reduction of the DPPH radical absorbance.

\section{Results and Discussion}

Methanolic extracts of nineteen selected Nepalese traditional anti-diabetic medicines were screened for their anti-oxidative activity by DPPH radical scavenging method. All of these extracts showed certain activity at concentration dependant manner (Table 1). Among them, the extracts of Phyllanthus emblica (fruit), Punica granatum (fruit peel), Syzygium cumini (fruit), Terminalia bellirica (fruit) and Terminalia chebula (fruit) have shown more than $89 \%$ free radical scavenging activities at $10 \mu \mathrm{g} / \mathrm{ml}$ concentration level (Table 1). These five extracts along with ascorbic acid were further analyzed at the lower concentrations of 1, 2, 5, 10, 15 and $20 \mu \mathrm{g} / \mathrm{ml}$ for the calculation of the $\mathrm{EC}_{50}$ values.

The $\mathrm{EC}_{50}$ values for P. emblica, T. chebula and $T$. bellirica were found as $3.1,3.3$ and $3.7 \mu \mathrm{g} / \mathrm{ml}$, respectively, which was lower than that of ascorbic acid (3.9 $\mu \mathrm{g} / \mathrm{ml}$ ) (Fig. 1). Phenolic compounds present in these plant species may have role in the antioxidant activity. Previous studies have reported that the traditional Ayurvedic formulation Triphala (equi-ratio of P. emblica, T. chebula and T. bellirica fruits powder) were found to inhibit lipid peroxide formation and to scavenge hydroxyl and superoxide radical in vitro (Sabu \& Kuttan 2002).



Fig. 1. $E_{50}(\mathrm{~g} / \mathrm{ml})$ value of the potent traditionalmedicines

Azardichta indica, Momordica charantia and Trigonella foenum-graceum are very common and considered as effective traditional anti-diabetic drug 
in Nepal. The hypoglycemic activities of the individual drug are also widely studied. However, the antioxidative properties of these drugs were found to be very low (Table 1 ). In the meantime, it is very common practice that diabetic people in Nepal take A. indica, M. charantia and/or T. foenum-graceum together with Triphala. The herbal practitioner and patients often claim on the improvement of glycemic condition by taking combined prescription, however we did not find any systematic study so far.

This study suggested that radical scavenging activity may be one of the pathways to show further beneficial effects of these traditional medicines in the treatment of diabetes in combination with modern drugs. Further studies on the activity guided isolation of the potent antioxidant constituents from these medicines and evaluation of other mechanism for anti-diabetic activity may help in better understanding of diabetes treatment.

\section{Acknowledgements}

We would like to thank University Grants Commission (UGC), Sanothimi, Bhaktapur, Nepal for partial financial support to this project.

\section{References}

Asplund, K. 2002. Antioxidant vitamins in the prevention of cardiovascular disease: A systemic review. Journal of Internal Medicine 251: 372-392.

Basnet, P., S. Kadota, R.R. Pandey, T. Takahashi, Y. Kojima, M. Shimizu, Y. Takata, M. Kobayashi and T. Namba. 1995. Screening of traditional medicines for their hypoglycemic activity in streptozotocin (STZ)-induced diabetic rats and a detailed study on Psidium guajava. Journal of Traditional Medicines 12: 109-117.

Beckman, K.B. and B.N. Ames. 1996. The free radical theory of aging matures. Physiological Reviews 78: 547-581.

Bnouham, M., A. Ziyyat, H. Mekhfi, A. Tahri and A. Legssyer. 2006. Medicinal plants with potential antidiabetic activity- A review of ten years of herbal medicine research (1990-2000). International Journal of Diabetes and Metabolism 14: 1-25.
Chalise, J.P., K. Acharya, N. Gurung, R.P. Bhusal, R. Gurung, N. Skalko-Basnet and P. Basnet. 2010. Antioxidant activity and polyphenol content in edible wild fruits from Nepal. International Journal of Food Science and Nutrition 61: 425-432.

Delagarza, V.W. 2003. Pharmacological treatment of Alzheimer's disease: An update. Americal Family Physician 68: 1365-1372.

Devkota, H.P., A. Adhikari, S. Paudel,; Sushila G. C.; A. Takano and P. Basnet. 2006. Antioxidative activity of common natural medicines in Nepal. Journal of Nepal Pharmaceutical Association 24, 39-46.

Droge, W. 2002. Free radicals in the physiological control of cell functions. Physiological Reviews 82: 47-95.

Evans, J.L., I.D.Goldfine, B.A. Maddux and G.M. Grodsky. 2002. Oxidative stress and stress-activated signaling pathways: A unifying hypothesis of type 2 diabetes. Endocrinology Reviews 23: 599-622.

Kaneto, H., J. Fujii, H.G. Seo, K. Suzuki, T. Matsuoka, M. Nakamura, H. Tatsumi; Y. Yamasaki, T. Kamada and N. Taniguchi. 1995. Apoptotic cell death triggered by nitric oxide in pancreatic $\beta$-cells. Diabetes 14: 733-738.

Manandhar, N.P. 2002. Plants and People of Nepal. Timber Press, Inc., Portland.

Packer, L., P. Rosen, H.J. Tritschler, G.L. King and A. Azzi. 2000. Antioxidants in diabetes management. Marcel Dekker, Inc., New York.

Robertson, R.P. 2002. Chronic oxidative stress as a central mechanism for glucose toxicity in pancreatic islet beta cells in diabetes. Journal of Biological Chemistry 279: 42351-42354.

Turk, J., J.A. Corbett, S. Ramanadham, A. Bohrer and M.L. McDaniel. Biochemical evidence for nitric oxide formation from streptozotocin in isolated pancreatic islets. Biochemical and Biophysical Research Communications 197: 1458-1464.

Sabu, M.C. and R. Kuttan 2002 Anti-diabetic activity of medicinal plants and its relationship with their antioxidative property. Journal of Ethnopharmacology 81: $155-160$.

Vincent, A.M., J.W. Russel, P. Low, E.L. Feldman. 2004. Oxidative stress in pathogenesis of diabetic neuropathy. Endocrinology Reviews 25: 612-628.

Wild, S., G. Rogic,; Green, A.; Sicree, R.; King H. Global prevalence of diabetes: Estimates for the year 2000 and projections for 2030. Diabetes Care 27: 1047-1053 (2004). 